\title{
Innovative technologies of geoinformation support for hydraulic structures
}

\author{
Sergey Lukyanov ${ }^{1, *}$, Alexander Averkiev ${ }^{1}$, Alexander Rybalko ${ }^{2,3}$, Yuri Tatarenko ${ }^{1}$, Natalia \\ Frolova ${ }^{1}$, and Oleg Shevchuk ${ }^{1}$ \\ ${ }^{1}$ Russsian State Hydrometeorological University, Voronezhskaya str. 79, Saint-Petersburg, 192007 \\ Russia \\ ${ }^{2}$ FSBI "VNIIOkeangeologiya”, Angliyskiy av., 1, Saint-Petersburg, 190121, Russia \\ ${ }^{3}$ St. Petersburg State University, Universitetskaya Emb., 7-9, Saint-Petersburg 199034, Russia
}

\begin{abstract}
The paper presents the technologies of geoinformation support within hydraulic structures construction and exploitation at the stage of engineering-geological, engineering-ecological and engineeringhydrometeorological surveys for environmental economics during the implementation of major projects in the field of sustainable development of cities and municipalities. The impact of dredging on the natural environment is considered, and a conclusion about the need to study the rate of sedimentation at different stages of exploration, design, construction, and operation of underwater engineering facilities are made. It is shown how the construction of the Marine Facade of St. Petersburg for receiving tourist ferries changed the need for dredging volumes and how this affected the total cost of work. The port of Bronka in Neva Bay is used as an example of sedimentation study during the period of 2005-2007. The developed technologies should help in managing natural risks in the implementation of major projects in the field of construction and operation of hydraulic structures within the framework of the environmental economics in a changing climate.
\end{abstract}

\section{Introduction}

Within environmental economics, an important aspect is the management of environmental risks during the implementation of large projects, for example, in the field of sustainable development of cities [1-5] and municipalities [6], or in the field of environmental management [7], including coastal zones [8], While such risk management we propose to use geo-information support [9-11], based on the principles of geoinformation management of complex geographically distributed systems [12-17]. If the projects are implemented in the Arctic and subarctic regions [18], the composition of natural risks must take into account climate change, due, inter alia, the influence of the inflow into the Arctic ocean of Pacific and Atlantic waters [19, 20], the flow of Arctic rivers, as well as black carbon [21].

\footnotetext{
* Corresponding author: serg.luknv@mail.ru
} 
Modern metropolitan areas are often located on the coastline. Many of them develop as seaports with associated infrastructure. Generally speaking, coastline metropolitan areas play a key role in economic development of not only the adjacent regions, but also of the whole country, since they are parts of the international trade system.

The development of port infrastructure is determined by the types of transported goods, the corresponding access routes on land, and natural conditions of the water body. Therefore, marine hydrotechnical structures must both comply with economic parameters and fit smoothly into the urbanized landscape, maintaining to the greatest possible extent the sustainability of natural ecosystems (in this case already natural-technical systems). The prime example of the mutual influence of economic development and aspiration to preserve coastal ecosystems is the practice of hydrotechnical construction in St. Petersburg, in particular, during the construction and operation of the St. Petersburg Flood Protection Complex and the Marine Facade terminal for cruise ships [22].

One of the main tasks of hydrotechnical engineering is dredging, or transportation of bottom soils. The process includes three main stages: excavation (dredging), transfer of the excavated soil on land or discharge into underwater dumps and hydraulic filling of new territories. During the construction of the Marine Facade complex all these three stages took place. The plan was to remove about 40 million cubic meters of bottom sediments. The cost of work for different types of soils and methods of transportation varied from $\$ 3$ to $\$ 8$ per cubic meter for dredging itself. The filling of territories, environmental damage fee, the actual construction of hydraulic structures and their subsequent maintenance required additional financing.

During the first stage of the Marine Facade construction project, in several years above 20 million cubic meters of grounds were dumped into underwater dumps of North and South Lakhta. In the course of the work, it was found out that for proper functioning of the new passenger terminal and the promising development of other port structures in the eastern part of Gulf of Finland, another 240 million cubic meters of bottom ground have to be moved. Although these plans are still under discussion, it is clear that such large-scale work will require further funding. All the fairways must always be maintained in working condition i.e. repair dredging to the desired depth mark may be required. That is when it is necessary, as in the beginning of hydraulic engineering construction, to use instrumental measurements and modeling of the dynamics of sediment load and rate of accumulation of surface sediments, what is mainly covered in this article.

In article, we present the results of the development in innovative technologies for hydraulic construction and exploitation for environmental economics, including tasks of natural risk management during the implementation of major projects in the field of sustainable development of cities and municipalities in the context of climate change.

\section{Methods and data}

We used in research: Foresight technologies, risk management approach, theory of decision making under uncertainties, methods of data bases (DB) constructing. From the point of view of geographic information management, we structured geo-space to allocate the interconnected components of the solution space [13, 14]. We use remote sensing to estimate the sizes of increased turbidity areas, formed during dredging (dredging, dumping of soil into underwater dumps and land reclamation). Geological, ecological and hydrometeorological engineering surveys are the most important measures of obtaining scientific information for design and construction of hydrotechnical construction.

\section{Results}


In recent decades, several large hydrotechnical facilities were constructed in the eastern Gulf of Finland and the Neva Bay: new marine channels in the Neva Bay that allow approaching the new harbor for cruise ships and the Konstantinovsky Palace, the harbor itself at the Vasilievsky Island, the largest port in the Luga Bay, two oil terminals in Vysotsk and Primorsk, the flood protection complex for the new port in Bronka. Large amounts of bottom sediments were excavated during these engineering works, and construction on the coast (deep-water berths, port facilities, etc.) ultimately followed.

In Fig. 1-3, we present the satellite images of the increased turbidity zones that formed as the result of excessive dredging in Neva Bay and the Eastern Gulf of Finland within 2006-2009 years, illustrating the distribution of suspended matter in the water area in the period 2006-2009, including for different conditions of removal and discharge of ground.

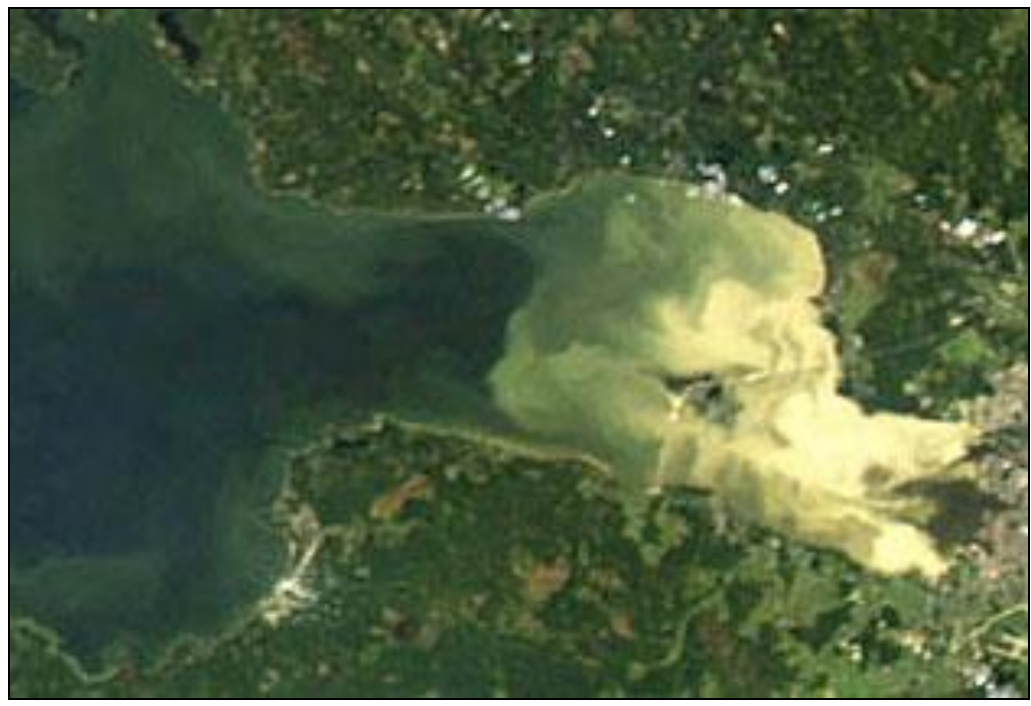

Fig. 1. Fragments of satellite images 11.09.2006 of the Neva Bay and the Eastern Gulf of Finland according to the MODIS radiometer (Aqua satellite).

Satellite images in fig. 1-3 provided by L. L. Sukhacheva as part of the implementation of the State contract commissioned by Rosprirodnadzor. Environmental damage fee for that was charged in accordance with the legal standards of Russian Federation.

The sizes of spots of increased turbidity, formed during dredging (dredging, dumping of soil into underwater dumps and land reclamation) directly determine the cost of compensation for damage to the environment. As an example, let's take the design calculations of a very small area near the Sambian Peninsula. Here, over the entire 20 -year period, about 80 thousand cubic meters of mud accumulated on the area of near16.5 thousand $\mathrm{m}^{2}$ in the area of repair dredging. Extracted ground is traditionally stored on the land shore dump. The total duration of the work is 118 days, of which 52 days were dredged. The bottom areas covered with a layer of fluid mud outside the work area range from 73 thousand $\mathrm{m}^{2}(1 \mathrm{~mm})$ to 5 thousand $\mathrm{m}^{2}(5 \mathrm{~mm})$. Suspension plume with a concentration above the preset existed for about 450 hours. The average distance of the suspension plume was from $100 \mathrm{~m}$ to $500 \mathrm{~m}$.

Compensation of damage to aquatic biological resources in the Vistula Lagoon due to the formation of zones of increased turbidity and undermining the food supply of fish is estimated in the form of the cost of remedial measures. The volume of release of Atlantic salmon yearlings (salmon) to restore the disturbed state of aquatic biological resources is 35 thousand fry. 


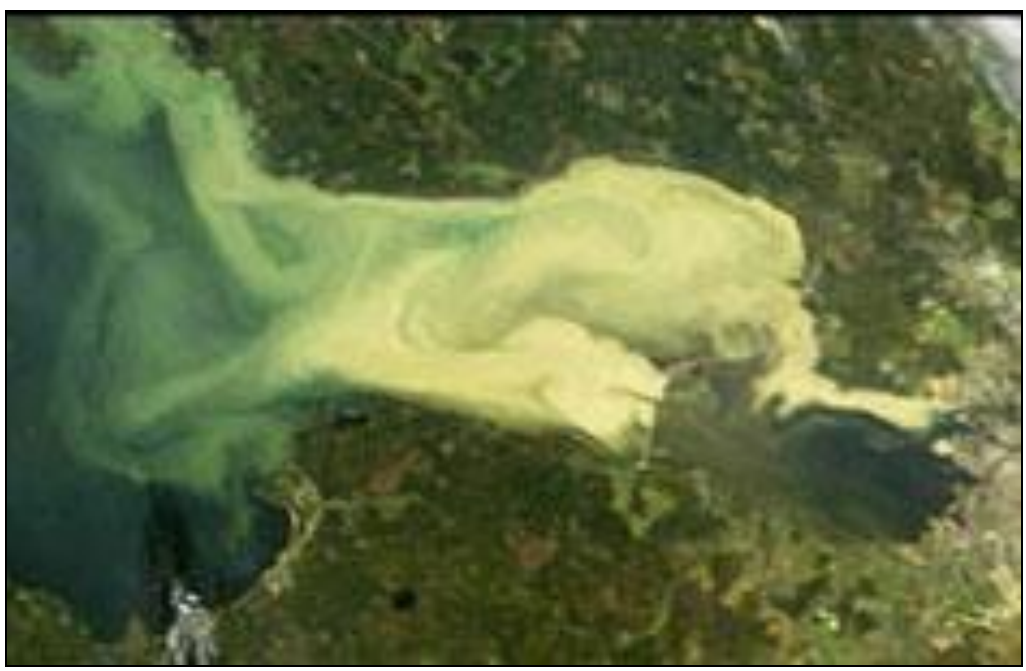

Fig. 2. Fragments of satellite images 30.09.2007 of the Neva Bay and the Eastern Gulf of Finland according to the MODIS radiometer (Terra satellite).

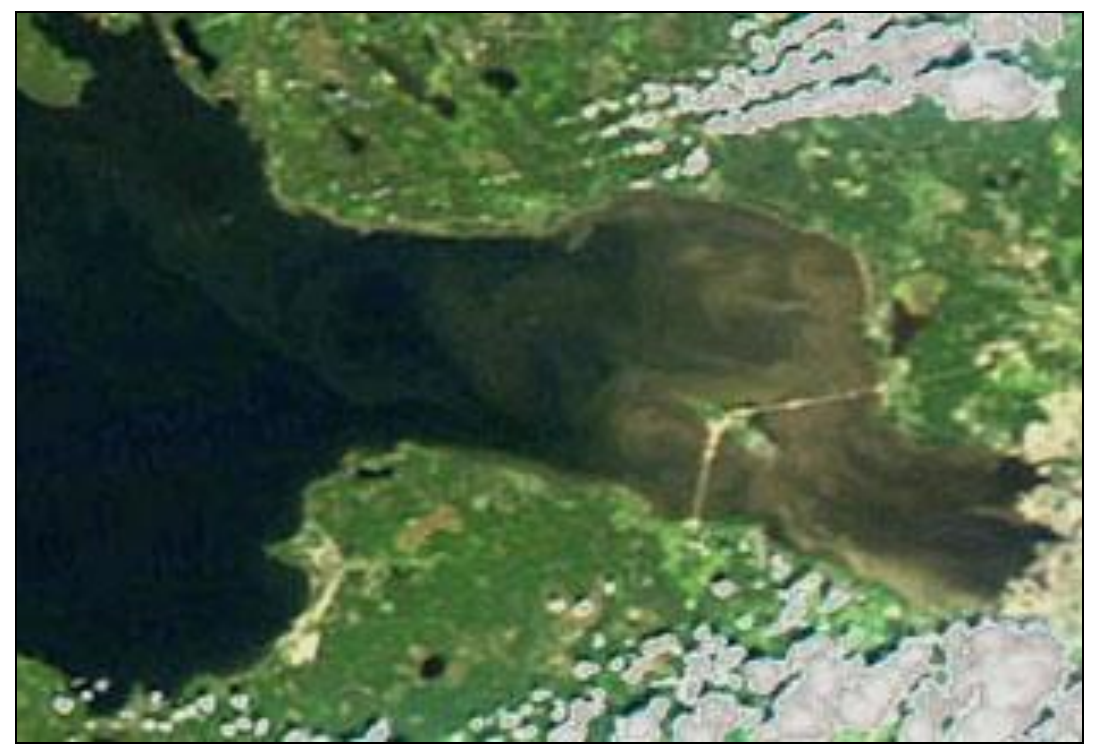

Fig. 3. Fragments of satellite images 21.06.2009 of the Neva Bay and the Eastern Gulf of Finland (Aqua satellite).

Duration of work also affect their total cost. As can be seen from the above satellite images, the area of increased turbidity in different periods during the construction of the Marine Facade occupied the entire Neva Bay $\left(380 \mathrm{~km}^{2}\right)$. The first phase of construction lasted 4 years at a project cost of 31 billion rubles (Federal budget and private investors).

Raw data on character, stratification, and physic-mechanical properties of bottom sediments, features of modern sedimentation, as well as the potential impact of the project on the environment is obtained directly from the source [22]. The formation of sediments' properties is closely related to hydrologic characteristics of the water basin. Special attention has to be devoted to the so-called "geo-hazards" - natural processes in the geologic environment that can directly affect engineering objects, up to their complete destruction. Currently in the area of discussion geo-hazards include: gas accumulations in 
bottom sediments prone to spontaneous release; seismic-gravitational events on law angle slopes, frozen soils (in the Arctic seas); ice scouring of the bottom by icebergs, or underwater parts of hummocks; rugged seabed; bottom currents causing lithodynamic flows of sedimentary material. Specifically, in the Neva Bay and the eastern Gulf of Finland, where the bottom topography predominantly even, hydro-lithodynamic processes can be considered geo-hazards. Micro-gravitational processes can develop only on relatively steep but low walls of artificial hydrotechnical objects (shipping channels, artificial harbors and underwater quarries for mining loose building materials).

\section{Discussion}

Let' $\mathrm{s}$ discusses the results from environmental economics point of view. In recent decades, several large hydrotechnical facilities were constructed in the eastern Gulf of Finland and the Neva Bay: new marine channels in the Neva Bay that allow approaching the new harbor for cruise ships and the Konstantinovsky Palace, the harbor itself at the Vasilievsky Island, the largest port in the Luga Bay, two oil terminals in Vysotsk and Primorsk, the flood protection complex for the new port in Bronka. Large amounts of bottom sediments were excavated during these engineering works, and construction on the coast (deepwater berths, port facilities, etc.) ultimately followed. All this artificial interruption to the coastal zone led to such changes in the structure as straightening of the coastline and fundamental change in the nature of coastal zones. At the same time, wetland areas that were typical for coastal zones of Neva Bay reduced significantly. It is enough to note that, according to various estimates, since 1703 , not more than $10 \%$ of the original coastlines in the Neva Bay have been left intact. Artificially created coastline include not only brick walls in harbors and concrete coastal reinforcement, but also coastline naturally forming in industrial setting. All projects included preliminary geological engineering and other surveys, and environmental impact assessment which indicated levels of environmental hazard for a facility. Environmental preservation measures of control were also introduced [23].

As noted above, the dredging process includes three parts: dredging at the construction site, transportation of the raised ground to the dumps and dumping of the ground. The first problem is the actual dredging at the construction site. Ideally, geological engineering surveys conducted prior to the start of dredging should assess the following parameters: the particle size distribution of the excavated soils, especially fine-grained fraction that can get suspended in water; rate of modern sedimentation; composition of suspended matter; amount of suspended material released at the area of work (i.e., the actual balance of incoming, accumulated and removed sediments). The latter task is closely related to the characteristics of the hydrological and, in part, hydro-meteorological regimes. A separate task is the environmental impact assessment indicating the way to minimize industrial impact on the existing environment. These are the tasks for different types of engineering surveys, but their careful implementation and unification of obtained information will help not only to choose the most economically viable option for construction and subsequent operation of a facility, and reduce environmental impact as much as possible, but also to build positive media coverage of certain hydrotechnical constructions.

The sedimentation rate, initially measured prior to the start of work, changing during the work itself and established after the completion of the facility, is one of the main elements of the predicted influence estimates from hydrotechnical objects. This can be illustrated by the example of engineering and hydrological surveys conducted by the authors in the port of Bronka (Leningrad Region). As a result of dredging during the creation of connecting channels, the geo-ecological situation significantly changed in the study area - the content of suspended matter in water dramatically increased, and so did the rate of sedimentation. To study this issue, as well as to determine the material composition accumulating on the 
bottom sediments, including the content of pollutants, we used sediment traps. In fig.4, we show the scheme of their setting. In fig. 5 we present the measured velocities, direction of currents (the field of currents), and the transparency of water (in meters), measured with the Secchi' disk.

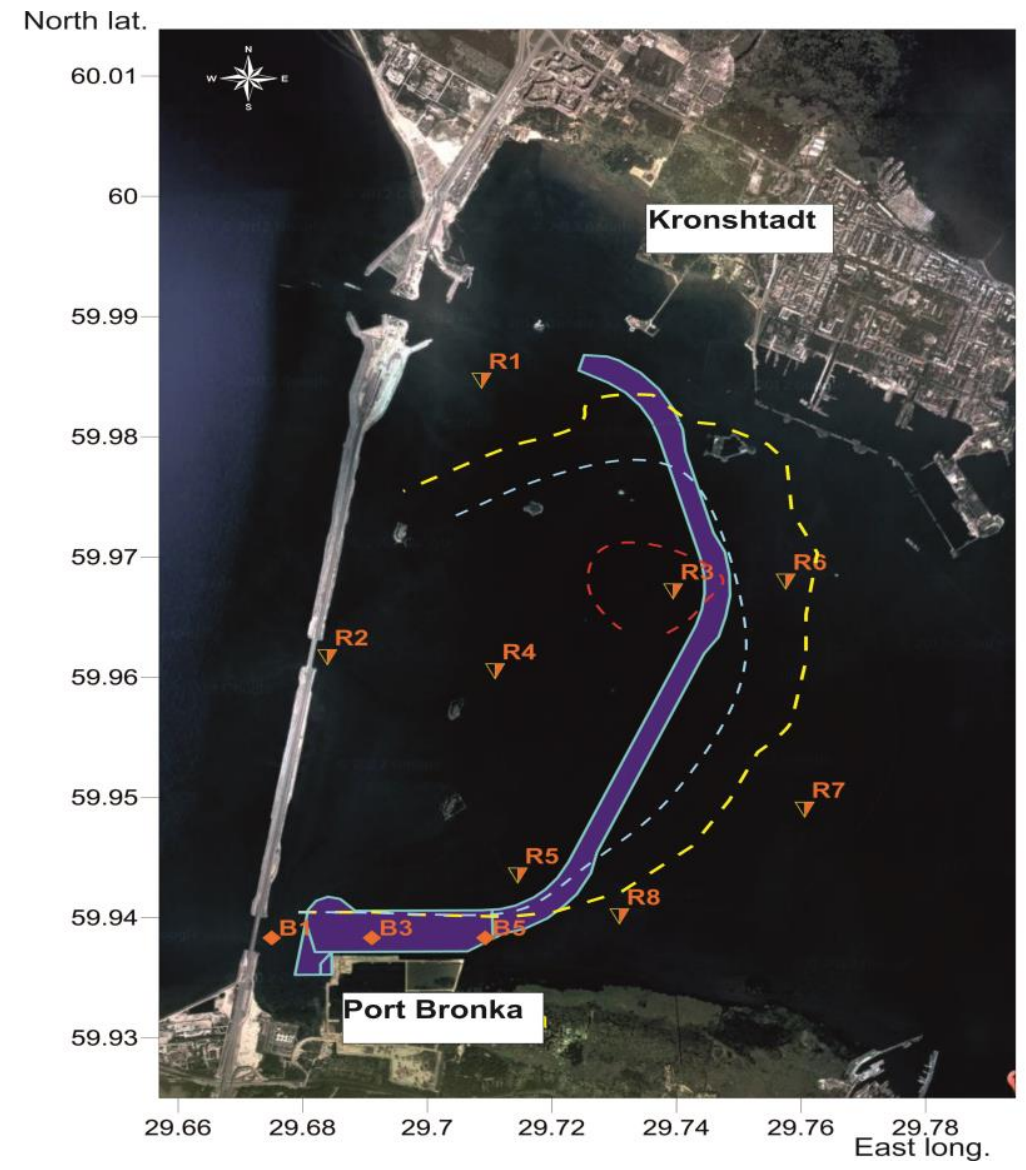

Fig. 4. Installation points for sedimentation traps and conditional rates of sediment accumulation (min- external dotted line). The author of the picture is Rybalko A.E.

We used cylindrical sedimentation traps made at State Company "Sevmorgeo" and Russian State Hydrometeorological University (RSHU), with about $1 \mathrm{~m}$ long and entrance diameter of $4.5 \mathrm{~cm}$. In all traps, accumulative plastic cylinders were fixed on a special metal rod with a stable base and were located $1 \mathrm{~m}$ above the bottom surface underwater in the accumulation zone. Bases of the traps were securely immobilized with additional loading. The length of the collecting plastic cylinder ranged from 60 to $70 \mathrm{~cm}$, the internal diameter of the inlet was $9.5 \mathrm{~cm}$. The ratio of height to diameter of the inlet was more than 6.

The maximum rates (over $0.08 \mathrm{~cm} /$ year) are fixed at stations R2 and R3, the first of them is located at the bend of the channel, where dredging was carried out during the measurement period, and the second at the culvert B-2. 


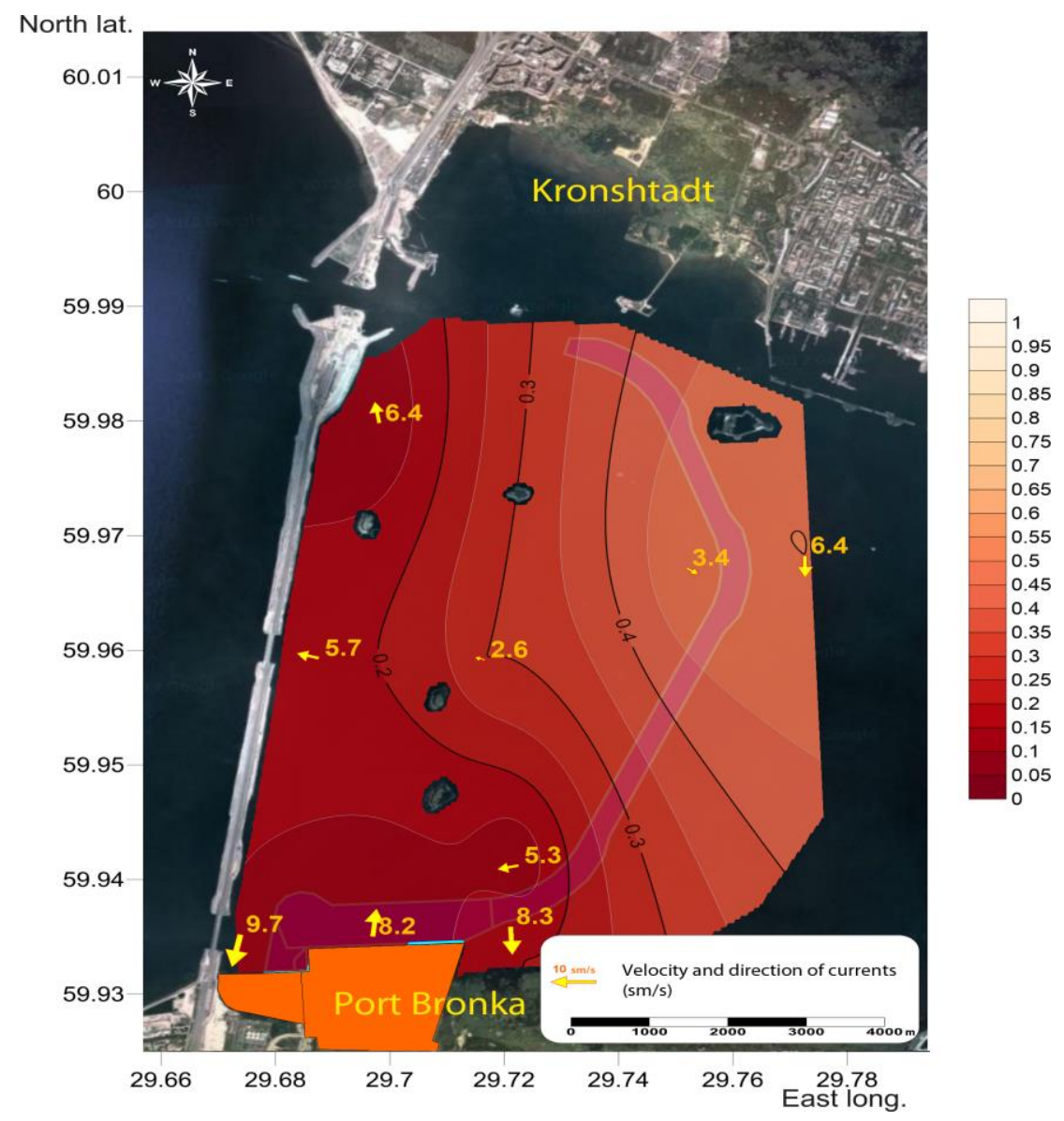

Fig. 5. The field of currents in the area of work 04.11.2015. on the surface and the amount of transparency by the Secchi disk method. The author of the picture is Maslov P.A.

It is through (as well as through the S-1 navigation terminal) that most of the suspended material released into the water during dredging of both the port water basin and the approach channel, passes protective structures and moves towards the open part of the Gulf of Finland. In the most part of the water area located between the approach channel under construction and the body of the dike, from 2 to $2.5 \mathrm{~cm}$ of suspended material accumulate annually (fig.6). Obtained data shows that in the observed time interval, most of suspended matter moved towards the $\mathrm{C}-2$ culvert to the south-west. The minimum sedimentation rates were recorded along the mooring line under construction, which is most likely due to pause in dredging. At the same time, a significant amount of suspension containing sandy particles settles directly at the port construction site, and the silty component is carried farther through the culvert.

Directly in the channel the sedimentation rate of suspensions was $0.087 \mathrm{~cm}$ per day (that is $1.2 \mathrm{~g}$ of suspended material accumulated per day). In the direction of the culvert, the sedimentation rate decreases slightly and varies between $0.078-0.083 \mathrm{~cm}$ per day.

Combined maps of transparency and flow vectors (Fig. 6) confirmed this conclusion and demosntated that the suspension release to the west occurs predominantly at an average speed of about $5.7 \mathrm{~cm} \mathrm{~s}^{-1}$ [23]. 


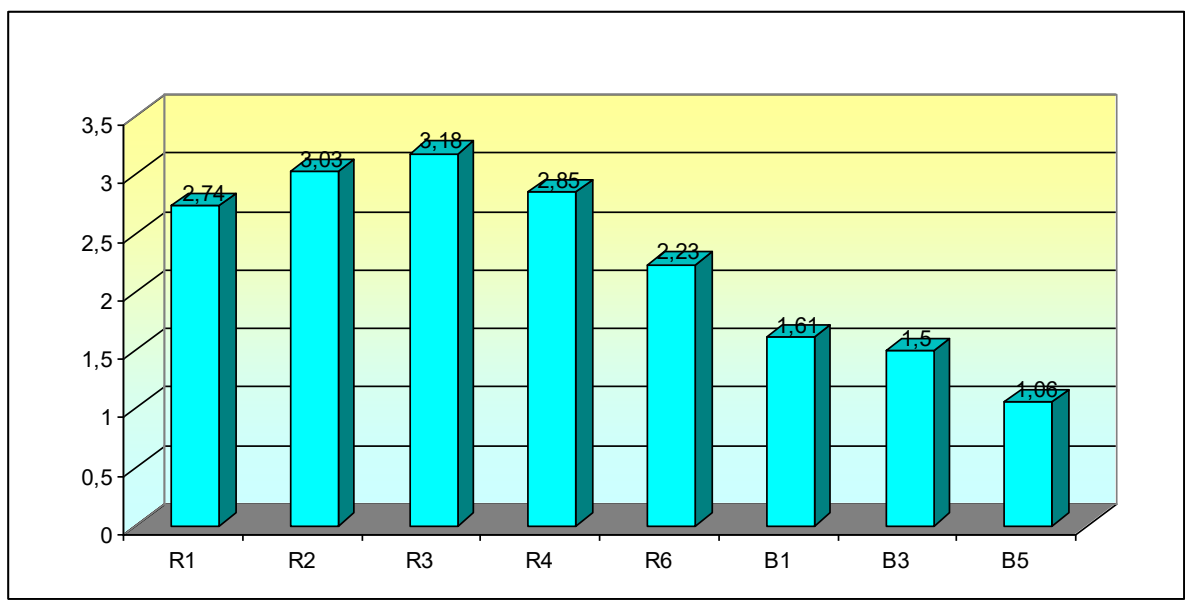

Fig. 6. Graph of sedimentation rate of suspended matter by stations ( $\mathrm{cm} /$ year).

It should be noted that, as the wind regime changed, so did the character of lithodynamic processes. With intense western winds, there was an increase in the velocity of bottom currents (up to $8.7 \mathrm{~cm} \mathrm{~s}^{-1}$ ), but their direction changed to the east, that is, to the Neva Bay. Incoming water diluted the suspension concentration in the Neva bay, moving its maximum from the dam to the east. However, the general tendency to move the suspension, including under the pressure of the Neva flow, was maintained.

Construction of the flood protection complex lasted for more than 30 years. Design calculations were made before construction, during and after its completion. However, even the simplest question of the height of the dike wall can be discussed further. The initial designed height was $8 \mathrm{~m}$, what was legit for the reason that the maximum level rise was $5 \mathrm{~m}$ plus the height of the waves during storm winds - up to $3 \mathrm{~m}$. Such extreme conditions can be observed with a probability of 0.0001 , that is, once every 10,000 years. However, recent modelling and calculations indicate that due to particularly dangerous cyclones the level rise can reach $6 \mathrm{~m}[22,23]$, and the frequency of dangerous deep and fast cyclones has increased in recent decades, possibly due to climatic changes [24] (climate warming).

\section{Conclusions}

The completed research reveals that within scientific information support for engineering works in the zones of under construction or designed underwater objects, the study of sedimentation rate is one of the most effective indicators for assessing lithodynamic parameters of the aquatic environment. Performed lithodynamic studies near of the Bronka port at the time of its construction showed that, starting in 2014, the general lithodynamic structure of sedimentary flows from the Neva Bay to the eastern part of the Gulf of Fing transformed. The flows reoriented to the southern section of the flood protection complex. The suspended material obtained during dredging in the area of the port of Bronka had predominantly silty to sandy composition, which caused its fairly rapid deposition and limited distribution in the Eastern Gulf of Finland.The construction and operation of the flood protection comolex demonstrates that constant monitoring of water level is required, especially during storms. Advanced modelling of storm wave patterns and bottom soil dynamics is expected to be promising within the area.

\section{References}


1. A. Burmistrov, M. Siniavina, O. Iliashenko, E3S Web of Conferences 33, 03005 (2018)

2. V. Vilken, O. Kalinina, A. Dubgorn, E3S Web of Conferences 33, 03012 (2018)

3. A. Izotov, O. Rostova, A. Dubgorn, E3S Web of Conferences 33, 03008 (2018)

4. M. Beekmann, Atmos. Chem. Phys. 15, 9577-9591 (2015)

5. C. Samara, D. Voutsa, A. Kouras, K. Eleftheriadis, T. Maggos, D. Saraga, M. Petrakakis, Environmental Science and Pollution Research 21(3) (2014)

6. G. Gogoberidze, L. Karlin, V. Abramov, J. Lednova, 2014 IEEE/OES Baltic International Symposium (2014) DOI: 10.1109/BALTIC.2014.6887840

7. M.B. Shilin, V.A. Zhigulsky, V.M. Abramov, A.A. Ershova, International Multidisciplinary Scientific GeoConference Surveying Geology and Mining Ecology Management 18(5.1), 423-430 (2018)

8. G. Gogoberidze, N. Popov, V. Abramov, A. Ershova, J. Lednova, International Multidisciplinary Scientific GeoConference Surveying Geology and Mining Ecology Management 17(52), 951-958 (2017)

9. G. Gogoberidze, E. Rumyantseva, V. Abramov, N. Rodin, G. Vladimirova, International Multidisciplinary Scientific GeoConference Surveying Geology and Mining Ecology Management 17(52), 921-926 (2017)

10. A.A. Fokicheva, E.P. Istomin, V.M. Abramov, V.G. Burlov, A.G. Sokolov, International Multidisciplinary Scientific GeoConference Surveying Geology and Mining Ecology Management 18(2.2), 377-384 (2018)

11. J.A. Garcia, V.M. Abramov, E.P. Istomin, International Multidisciplinary Scientific GeoConference Surveying Geology and Mining Ecology Management 18(2.2), 261268 (2018).

12. V.G. Burlov, A.G. Sokolov, V.M. Abramov, E.P. Istomin, A.A. Fokicheva, International Multidisciplinary Scientific GeoConference Surveying Geology and Mining Ecology Management 18(2.2), 483-490 (2018)

13. E.P. Istomin, A.G. Sokolov, V.M. Abramov, G.G. Gogoberidze, N.N. Popov, International Multidisciplinary Scientific GeoConference Surveying Geology and Mining Ecology Management 1(2), 607-614 (2015)

14. A.A. Fokicheva, E.P. Istomin, A.G. Sokolov, V.M. Abramov, G.G. Gogoberidze, International Multidisciplinary Scientific GeoConference Surveying Geology and Mining Ecology Management 1(2), 729-736 (2015)

15. Popov N.N., Istomin E.P.,Abramov V.M., Burlov V.G., Sokolov A.G., Development of technology for environmental safety control based on geo-information systems / International Multidisciplinary Scientific GeoConference Surveying Geology and Mining Ecology Management, SGEM, 17(21), 859-866 (2017)

16. A.G. Sokolov, E.P. Istomin, V.M Abramov, V.G. Burlov, A.A. Fokicheva, International Multidisciplinary Scientific GeoConference Surveying Geology and Mining Ecology Management 17(21), 1005-1012 (2017)

17. L.S. Slesareva, E.P. Istomin, V.M Abramov, A.G. Sokolov, V.G. Burlov, International Multidisciplinary Scientific GeoConference Surveying Geology and Mining Ecology Management 17(21), 951-959 (2017)

18. J. Lednova, G. Gogoberidze, V.M. Abramov, L.N. Karlin, S. Berboushi, International Multidisciplinary Scientific GeoConference Surveying Geology and Mining Ecology Management 1(5), 161-168 (2014) 
19. L.V. Alexandrova, N.N. Popov, V.M. Abramov, G.G. Gogoberidze, L.N. Karlin, International Multidisciplinary Scientific GeoConference Surveying Geology and Mining Ecology Management 2(3), 701-708 (2015)

20. L.V. Alexandrova, A.V. Bournashov, V.M. Abramov, G.G. Gogoberidze, L.N. Karlin, International Multidisciplinary Scientific GeoConference Surveying Geology and Mining Ecology Management 2(3), 661-668 (2014)

21. V.M. Abramov, G.G. Gogoberidze, N.N. Popov, A.V. Isaev, S.V. Berboushi, International Multidisciplinary Scientific GeoConference Surveying Geology and Mining Ecology Management 1(4), 953-960 (2015)

22. O. Korneev, D. Ryabchuk, A. Rybalko, V. Zhamoida, A. Grigoriev, A. Sergeev, A. Evdokimenko, Reports of the Finnish Environment institute 27, 65-69 (2016)

23. A.S. Averkiev, K.A. Klevannyy, Continental Shelf Research 30(6), 707-714 (2010) DOI: $10.1016 /$ j.csr.2009.10.010

24. V.N. Malinin, S.M. Gordeeva, L.M. Naumov, A.A. Ershova, A.S. Averkiev, Fundamentalnaya i Prikladnaya Gidrofizika 11(4), 28-33 (2018) DOI: $10.7868 /$ S2073667318040044 